dence of mumps infection has been variously estimated as between 0.8 and 10 cases per 100 pregnancies. ${ }^{3}$ During mumps, virus initially replicates in the epithelium of the upper respiratory tract. A viraemia follows, and there is often prolonged excretion of virus in the urine for two to three weeks. Only six cases of mumps virus infections occurring at the end of pregnancy have been described. ${ }^{34}$ Four infants developed a parotitis during the first week of life, one child remained asymptomatic, and no virus was isolated. One child was admitted on the seventh day of life with high fever and respiratory distress, which resulted in a week of ventilation. ${ }^{1}$ The outcome was good and one year later the child was still well. Common features with our case were general illness, respiratory distress, latent period, and good prognosis after symptomatic treatment.
Mumps infection in the newborn can be misleading because of the lack of apparent parotitis or meningitis. It emphasises the value of systematic early virologic studies in any neonatal infection.

\section{References}

1 Jones JF, Ray GG, Fulginiti VA. Perinatal mumps infection. J Pediatr 1980;96:912-4.

2 Kurts JB, Tomlinson AH, Pearson J. Mumps virus isolated from a fetus. Br Med J 1982;284:471.

${ }^{3}$ Young NA, Gershon AA. Measles and mumps. In: Infectious diseases of the fetus and newborn infant. Remington JS, Klein JO, eds. Philadelphia: W B Saunders Company, 1983; 375-427.

${ }^{4}$ Dumont M. Oreillons au cours de la grossesse. Nouv Presse Med 1978;7:4302-3.

Correspondence to Professor F Freymuth, Laboratö̈re de Virologie, CHRU, 14040 Caen Cedex, France.

Received 8 October 1985

\title{
Comparison of ultrasound examination and intravenous urography after a urinary tract infection
}

\author{
D LINDSELL AND M MONCRIEFF
}

John Radcliffe Hospital, Oxford

SUMmary The results of ultrasound examination and intravenous urography after a urinary infection were compared in 100 children. Thirty seven had an abnormality on urography, but in 12 this was not seen on ultrasound. One of these had renal scarring, the remainder only minor abnormalities.

Investigations after a urinary tract infection are carried out to detect factors predisposing to infection (obstruction lesions and gross vesicoureteric reflux) and early renal scarring. Until recently this involved an intravenous urogram (IVU) and micturating cystourethrogram in all children after the first infection. ${ }^{1}$ These investigations involve irradiation, are unpleasant, and have potential complications. A selective approach has been advocated with an IVU in all cases, a micturating cystourethrogram being deferred until a second infection in children with a normal IVU. ${ }^{2}$ This still means that an IVU is carried out on all children with an infection. Ultrasound examination is painless, free from side effects, and would be an acceptable alternative investigation if the abnormalities mentioned above could be reliably detected. A preliminary report comparing ultrasound and IVU in children with an infection showed only a small number $(10 \%)$ of false negatives. ${ }^{3}$ The age of the patients, however, was not given, and, as the risk of renal damage is much higher in young children, ${ }^{4}$ this is important. We report a study comparing ultrasound examination and IVU in 100 children, 59 of whom were under 5 .

\section{Material and methods}

One hundred children, 71 girls and 29 boys, were investigated after a urinary tract infection. The diagnosis of infection was based on urine culture showing $10^{5}$ or more organisms per $\mathrm{ml}$. Eleven were aged under 1 year, 48 between 1 and 5 , and 41 over 5 .

The renal tract of each child was imaged with ultrasound and then immediately afterwards by an IVU.

All ultrasound examinations were performed by one radiologist (DL) using the $5 \mathrm{MHz}$ probes of the Hitachi EUB-25 linear array scanner and the ATL mark 300 sector scanner. The kidneys were assessed for congenital anomalies and for evidence of renal scarring. Dilatation of the distal ureters was looked for closely as this might suggest reflux. If possible the pelvis was scanned when the bladder was full. 
After the ultrasound examination an IVU was performed using iopamidol (Niopam 300) in a dose of $2 \mathrm{ml} / \mathrm{kg}$. The number of films taken at each examination varied and was kept to the minimum that showed the renal outlines clearly, an opacified pelvicalyceal system, and a reasonably full bladder. In addition to structural abnormalities of the renal tract and evidence of renal scarring, particularly close attention was paid to changes such as minor calyceal blunting and ureteric dilatation that might suggest vesicouretric reflux.

The result of the ultrasound examination was reported first, and then compared with the IVU.

\section{Results}

The Table presents the results separately for the three age groups. Of the 11 babies aged under 1 , eight $(73 \%)$ had an abnormality on both ultrasound and IVU; the remaining three were normal on both examinations. Of the 48 children aged $1-5,18(38 \%)$ had an abnormality on IVU, but in seven this was not seen on ultrasound. In the 41 children over 5,11 $(27 \%)$ had an abnormality on IVU, but in five this was not seen on ultrasound. Thus there were 12 false negative results in 100 children on ultrasound examination compared with IVU. One was a 6 year old girl with bilateral scarring who had had at least two infections. Doubtful unilateral scarring was found in a 3 year old girl whose IVU showed a slightly irregular lateral margin of the left kidney. The calyces were normal, and this may have been fetal lobulation. Thus only one potentially serious condition was missed on ultrasound examination of these children. A further seven cases of scarring were detected on ultrasound examination, giving a false negative rate for renal scarring of $12 \%$. There were no false positives on ultrasound examination.

Table Abnormalities on IVU and ultrasound in 100 children after a urinary infection

\begin{tabular}{llll}
\hline & $\begin{array}{l}\text { Present on } \\
\text { IVU }\end{array}$ & $\begin{array}{l}\text { Present on } \\
\text { ultrasound }\end{array}$ & $\begin{array}{l}\text { Not seen on } \\
\text { ultrasound }\end{array}$ \\
\hline Hydronephrosis: & & & \\
$\quad$ With obstruction & 7 & 7 & 0 \\
$\quad$ Without obstruction & 1 & 1 & 0 \\
Renal scarring & 9 & 7 & 2 \\
Minor calyceal blunting & 8 & 2 & 6 \\
Dilated ureter & 4 & 1 & 3 \\
Calculus & 3 & 3 & 0 \\
Malrotation, dysplasia, & 4 & 4 & 0 \\
$\quad$ absent kidney & 1 & 0 & 1 \\
Hemivertebra & 37 & 25 & 12 (false \\
\hline Total & & & negatives) \\
\hline
\end{tabular}

\section{Discussion}

Most abnormalities that were not detected on ultrasound examination were cases of minor calyceal blunting, the importance of which is unclear, or mild ureteric dilatation, which is probably of no clinical importance. Obstructive lesions, which are surgically correctable, were reliably detected. Ultrasound examination detected seven out of eight definite cases of renal scarring, a false negative rate of $12 \%$.

On the basis of our results we feel that in children aged over 1 routine IVU, after a first urinary tract infection, with its possible risks and undoubted unpleasantness could be replaced by ultrasound examination. A plain $x$ ray film of the abdomen should be performed as ultrasound does not always detect calculi or skeletal abnormalities. If the child has a further infection an IVU could then be performed. In this way renal scarring that will have been missed in a few cases initially will be detected. The renal damage caused by a single further infection in a child with scarred kidneys is probably small as most damage has occurred by the time the child first presents, ${ }^{5}$ and we think this is an acceptable price for saving $50 \%$ of children with a urinary tract infection from IVU.

The kidneys of infants aged under 1 seem to be more vulnerable to scarring than older chiildren. ${ }^{6}$ IVU often fails to show the renal outline, due to the lower glomerular filtration rate, and so scarring is difficult to detect. Ultrasound examination to detect obstructive lesions and micturating cystography to detect severe reflux, with the potential of intrarenal reflux and renal scarring, would be logical investigations at this age. Any abnormality could be further defined by renal scintigraphy.

\section{References}

1 Smellie JM. Acute urinary tract infection in children. $\mathrm{Br} \mathrm{Med} \mathrm{J}$ 1970;iv:97-100.

2 Moncrieff MW, Whitelaw R. Value of cystography in urinary tract infections. Arch Dis Child 1976;51:893-5.

${ }^{3}$ Sherwood T, Whitaker RH. Initial screening of children with urinary tract infection: is plain film radiography and ultrasonography enough? Br Med J 1984;288:827.

4 Winberg J, Bollgren I, Kallaneus G, Mollby R, Svenson SB. Clinical pyelonephritis and focal renal scarring. Pediatr Clin North Am 1982:29:801-14.

5 Hodgson J. Reflux nephropathy: a personal historical review. AJR 1981;137:451-62.

${ }^{6}$ White RHR, Taylor CM. Prospective trial of operative versus non-operative treatment of severe vesicoureteric reflux: two years' observation on 96 children. Br Med J 1983;287:171-4.

Correspondence to Dr M Moncrieff, John Radcliffe Hospital, Headington, Oxford OX3 9DU.

Received 18 October 1985. 